\section{GOLDEN LANGUR TRACHYPITHECUS GEEI (KHAJURIA, 1956) FEEDING ON CRYPTOCORYNE RETROSPIRALIS (ROXB.) KUNTH (FAMILY: ARACEAE): A RARE FEEDING OBSERVATION IN Chirang Reserve Forest, ASSAM, INDIA}

Raju Das ', Hilloljyoti Singha ${ }^{2}$, Hemanta Kumar Sahu ${ }^{3}$ \& Kushal Choudhury ${ }^{4}$

${ }^{1}$ Nature's Foster, P.O. Box No. 41, Shastri Road, Bongaigaon, Assam 783380, India

${ }^{2}$ Centre for Biodiversity \& Natural Resources Conservation, Department of Ecology \& Environmental Science, Assam University, Silchar, Assam 788011, India ${ }_{1,3,4}$ P.G. Departments of Zoology, North Orissa University, Sri Ramchandra Vihar, Takatpur, Baripada, Odisha 757003, India

${ }^{4}$ Department of Zoology, Science College, Kokrajhar, Assam, India

${ }^{1}$ dasraju73@gmail.com, ${ }^{2}$ hilloljyoti.singha@gmail.com (corresponding author),

${ }^{3}$ hks_nou@yahoo.com, ${ }^{4}$ kushal.c8@gmail.com

The Golden Langur Trachypithecus geei Khajuria, 1956 is one of the rarest primates of South Asia. Because of its restricted distribution and numbers, it is listed under Schedule I of the Wildlife (Protection) Act of India (1972), assessed as Endangered on the IUCN Red List (Das et al. 2008), and under Appendix I of CITES. It is a leaf-eating, arboreal, canopy-dwelling langur endemic to India and Bhutan. It is found only in a small pocket of forests of north-western Assam, India and south-central Bhutan at the Indo-Bhutan border. It is distributed in India between the rivers Manas in the east, Sankosh in the west and Brahmaputra in the south.

A rare feeding behaviour of Golden Langur was observed in Chirang Reserve Forest $\left(26.30^{\circ}-26.52^{\circ} \mathrm{N} \&\right.$ 90.15-90.25드), Assam, during 2010 on four occasions; two in October and two in December. The Chirang
Reserve Forest is bounded on the west by the Saralbhanga River, on the north by the international boundary with Bhutan, on the east by the river Bhur, and on the south it is bounded at present by National Highway 31. The Chirang Reserve Forest is in the buffer area of the Manas Biosphere Reserve and Ripu-Chirang Elephant Reserve.

We observed a group of Golden Langurs feeding on Cryptocoryne retrospiralis (family: Araceae) in Samukha River. The group was composed of a total of 10 individuals consisting of two adult males, five adult females, two infants and one juvenile. The langurs would go down to the river, get a portion of the plant, and eat it as they moved on. The feeding bout lasted for two to three minutes, extending up to five minutes. On all these four occasions, langurs were found actively seeking the plant. On exposed stream beds, they would sit digging the plant until a piece was chosen and eaten. Movement to the site was direct, with clear intent. In eight cases, some bits of the plant that had been picked up were tasted, smelled and subsequently rejected. They fed on the stalks, leaves and flowers of the plant. In one instance a male went down to the water to feed on the whole plant (Image 1a). They purposefully fed on this plant species among other aquatic macrophytes. Adult males were the most frequent users of the plant.

Abbreviations: CITES - Convention on International Trade in Endangered Species of Wild Fauna and Flora; IUCN - International Union for Conservation of Nature; RF - Reserve Forest.

DOI: http://dx.doi.org/10.11609/JoTT.03535.5013-5 | ZooBank: urn:Isid:zoobank.org:pub:20AFFD4E-2A7A-4E5B-A824-A68B28666D64

Editor: Mewa Singh, Mysore University, Mysuru, India.

Date of publication: 26 November 2013 (online \& print)

Manuscript details: Ms \# 03535 | Received 20 February 2013 | Final received 28 August 2013 | Finally accepted 14 October 2013

Citation: Das, R., H. Singha, H.K. Sahu \& K. Choudhury (2013). Golden Langur Trachypithecus geei (Khajuria, 1956) feeding on Cryptocoryne retrospiralis (Roxb.) Kunth (Family: Araceae): a rare feeding observation in Chirang Reserve Forest, Assam, India. Journal of Threatened Taxa 5(15): 5013-5015; http://dx.doi.org/10.11609/ JoTT.03535.5013-5

Copyright: @ Das 2013. Creative Commons Attribution 3.0 Unported License. JoTT allows unrestricted use of this article in any medium, reproduction and distribution by providing adequate credit to the authors and the source of publication.

Funding: The first author is grateful to Dr. Nowel Rowe, Primate Conservation Inc., USA, for financial grants.

Competing Interest: None.

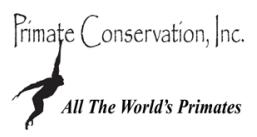

Acknowledgements: The authors wish to thank the Department of Forests and Tourism, Bodoland Territorial Council for granting the permission and logistic support. Sincere thanks are also due to Dr. Awadhesh Kumar, Department of Forestry, NERIST (Deemed University), Arunachal Pradesh, India for providing literature. The first author is grateful to Dr. R.H. Horwich, CC, USA for constant advice and support. 
Cryptocoryne retrospiralis (Roxb.) Kunth., also known as water trumpet, a submerged herb, is native to India, Bangladesh, Bhutan, Myanmar, Lao PDR, Vietnam and Thailand. It is commonly found all over India as a submerged herb (Gupta 2011). The plant is perennial, occurs mostly in streams and rivers with not too rapidly flowing water, and in lowland forest, where it often forms turf-like communities (Image 1b). The rhizomes of the plant grow up to $1.5 \mathrm{~cm}$ thick and knotty, with stolons, bearing long, thick, contractile roots, leaves linear to narrowly oblong, narrowly cartilaginous, sometimes minutely toothed near base. Spathe is pale green on the outside, with white spotted purple inside (Image 1c) (Noltie 1994). Flowering of the plants has been observed from November until March. However, this plant species is rare in Chirang Reserve Forest and is localized only in this part of the reserve forest. The water at the locality had a pH of 5-5.4.

Das (2012) reported 91 plant species as food species for Golden Langur comprising both trees and climbers in Chirang RF. Floristic composition of the habitat appears to determine the spectrum of food plant species in their diet. The proportion of foliage in the overall diet of Golden Langur is 70\% (Biswas et al. 1996). Consumption of young leaves probably meets the requirement of essential nutrients and protein for langurs because they contain a high percentage of crude protein (Struhsaker 1975; Krishnamani 1994; Kumar \& Solanki 2004). Golden Langurs get about $65 \%$ of their diet from leaves, $25 \%$ from fruits, and $10 \%$ from flowers (Das 2012). The selectivity and preferences of primates for specific plant species are viewed as strategies for dealing with the nutrient and secondary compound content variation in these foods (Das 2012). However, it is not clear why the Golden Langur select Cryptocoryne retrospiralis to feed on among other aquatic plant species. The chemical analyses have demonstrated that plant parts of Cryptocoryne sp. contain carbohydrates, glycosides and alkaloids, and very specifically contain oxofattyacid esters like ethyl 14-oxotetracosonoate and 15-oxocicosanyl 14-oxoheptadecanoate together with hentriacontane (Rastoji \& Mehrotra 1980). There are also reports of consumption of Cryptocoryne species as greens by the tribes in the Western Ghats of India (Narayanan \& Kumar 2007). Ethnobotanically this plant is used locally in medicine (Cook 1996). The fresh tuber paste is applied twice a day for relief from boils and burns (Kamble et al. 2010); used as antiperiodic, febrifuge, tonic, beneficial in infantile vomiting, cough and for abdominal troubles (Chatterjee \& Prakashi 2001). Therefore, further investigation is needed regarding the consumption of
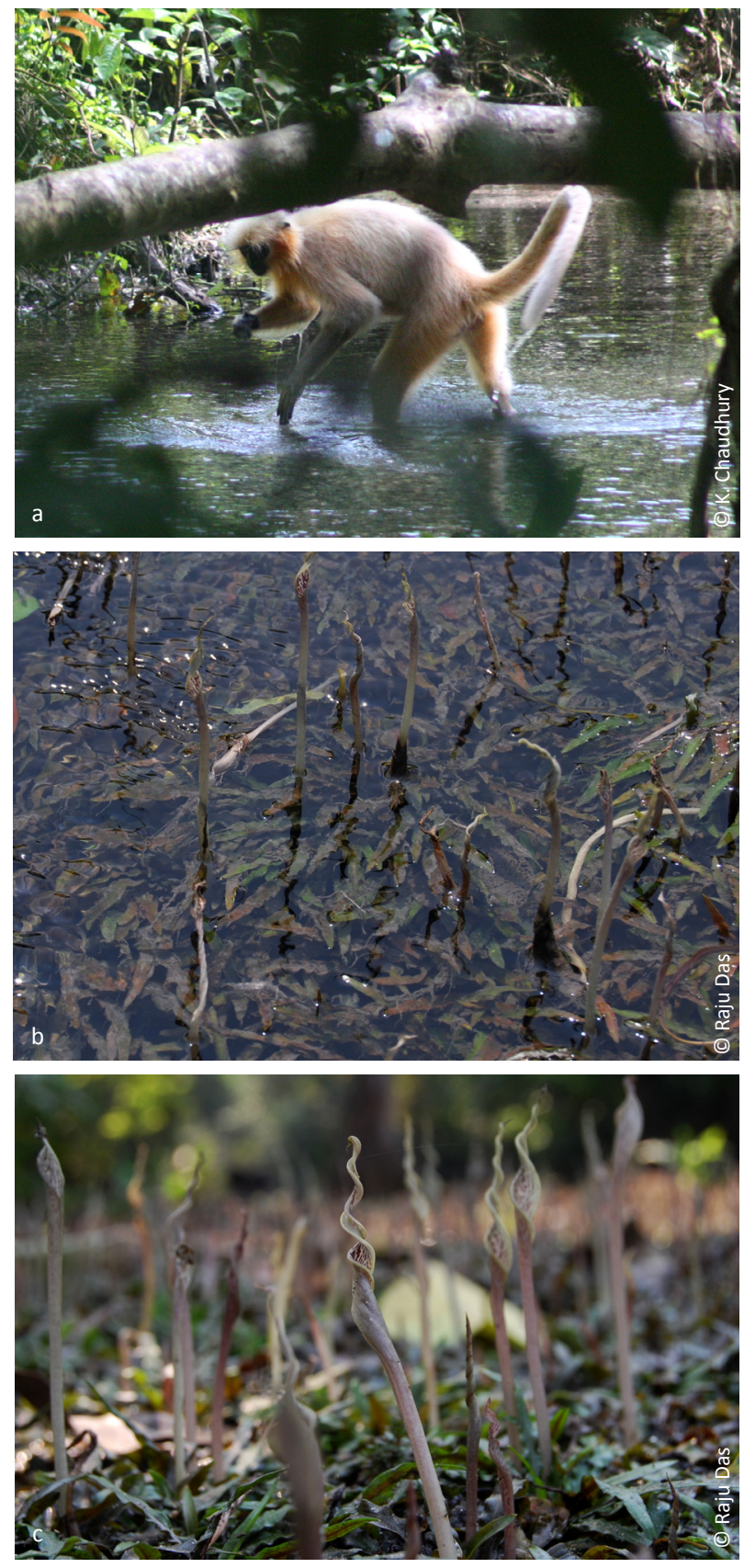

Image 1. a - Golden Langur feeding on the Cryptocoryne retrospiralis; $\mathbf{b}$ - habitat of the plant species; $\mathrm{c}$ - inflorescence of Cryptocoryne retrospiralis

Cryptocoryne retrospiralis by the Golden Langur.

\section{REFERENCES}

Biswas, J., R. Medhi \& S.M. Mohnot (1996). Behavior and ecology of introduced pair of Golden Langur to Umananda River Island, Assam (abstract) IPS/ASP Congress Abstracts. Madison, WI, USA, 041.

Chatterjee, A. \& S.C. Prakashi (2001). The Treatise on Indian Medicinal Plants - Vol. 6. NISCIR, New Delhi, 33-34pp.

Cook, C.D.K. (1996). Aquatic and Wetland Plants of India. Oxford 
University press Inc., New York, 385pp.

Das, R. (2012). Nutritional ecology of Golden Langur Trachypithecus geei (Khajuria, 1956) in Chirang Reserve Forest, Assam, India. Unpublished PhD Thesis. North Orissa University, Baripada, Orissa, xxii+305pp.

Das, J., R. Medhi \& S. Molur (2008). Trachypithecus geei. In: IUCN 2013. IUCN Red List of Threatened Species. Version 2013.1. <www. iucnredlist.org>. Downloaded on 12 November 2013.

Gupta, A.K. (2011). Cryptocoryne retrospiralis. In: IUCN 2013. IUCN Red List of Threatened Species. Version 2013.1. <www.iucnredlist. org>. Downloaded on 26 August 2013.

Kamble, S.Y., S.R. Patil, P.S. Sawant, S. Sawanth, S.G. Pawar \& E.A Singh (2010). Studies on Plants used in traditional medicine by Bhillatribes of Maharashtra. Indian Journal of Traditional Knowledge 9(3): 591--598

Khajuria, H. (1956). A new langur (Primates: Colobidae) from Goalpara District, Assam. Annual Maga-zine Natural History 12: 86--88.
Krishnamani, R. (1994). Diet composition of the Bonnet Macaque (Macaca radiata) in a tropical dry evergreen forest of southern India. Tropical Biodiversity 2(2): 285--302.

Kumar, A. \& G.S. Solanki (2004). A rare feeding observation on water lilies (Nymphaeaalba) by the Capped Langur (Trachypithecus pileatus). Folia Primatologica 75: 157--159.

Narayanan, R.M.K. \& N.A. Kumar (2007). Gendered knowledge and changing trends in utilization of wild edible greens in Western Ghats, India. Indian Journal of Traditional Knowledge 6(1): 204--216.

Noltie, H.J. (1994). Flora of Bhutan - Volume 3, Part 1. Royal Botanic Garden, Edinburgh, 155pp.

Rastoji., P.R. \& B.N. Mehrotra (1980). Compendium of Indian Medicinal Plants - Vol.3, 1980-1984. CDRI Lucknow and NISCI, New Delhi, 214pp.

Struhsaker, T.T. (1975). The Red Colobus Monkey. University of Chicago Press, Chicago, 311pp. 